\title{
Effect of seasonal variation on soil enzymes activity and fertility of soil in paddy fields of North Vanlaiphai, Mizoram, India
}

\author{
C. Vanlalveni, R. Lalfakzuala* \\ Laboratory of Microbiology, Department of Botany, Mizoram University, Aizawl 796004, India
}

\begin{abstract}
For sustainability in agricultural productions, familiarity of soil quality and manual improvement to create the best possible growing environment for plants are extremely important. In this study the quality of soil of a paddy field in North Vanlaiphai was investigated with respect to the change in seasons throughout the year. A total of five (5) soil samples were selected from various places of the paddy field, and soil fertility indicators such as $\mathrm{pH}$, total soil nitrogen (N), available phosphorus (Pav), exchangeable potassium (Kex), soil organic carbon $(\mathrm{SOC})$, soil organic matter (SOM) and soil enzymes viz. dehydrogenase, phosphatase and urease were analyzed using standard protocols. All the parameters except available phosphorus and exchangeable potassium were found to be highest during rainy season whereas lowest in summer.
\end{abstract}

Key words: Soil enzymes, physico-chemical properties, soil fertility.

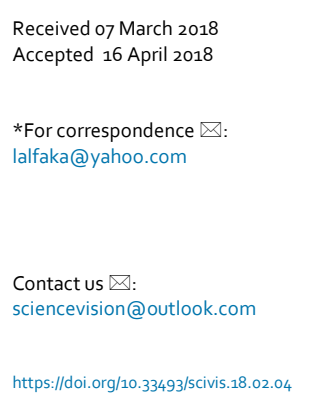

Received 07 March 2018

*For correspondence $\square$ lalfaka@yahoo.com

https://doi.org/10.33493/scivis.18.02.04

\section{Introduction}

In context of sustainable agricultural production, soil testing is very important as it provides the conditions of available nutrients which indicates the fertility and productivity of the soils. ${ }^{1}$ Nitrogen, phosphorus, potassium are important elements that dictate its fertility and yields of the crops. ${ }^{2}$ Agricultural lands are multifunctional, providing a range of regulating, supporting and cultural ecosystem services in addition to food, fodder, fuel and fibre. This 'underscores the need to manage agricultural areas as multifunctional systems... not as ecological sacrifice zones' ${ }^{3}$
Soil fertility is the capacity of a soil to supply essential plant nutrients in adequate amounts to facilitate optimum growth and production of a crop. Typically, inorganic nutrients such as $\mathrm{N}, \mathrm{P}$ and $\mathrm{C}$ are usually found at high concentration due to the anthropogenic influence (e.g. fertilization, wastewater, agricultural procedures). ${ }^{4}$ It was observed that the nutrient concentration changes along the crop cycle, very much related to the agricultural techniques used in the ricefields as well as with the sediment status. Soil fertility and quality play a pivotal role in achieving the promising yield of the crops. However, unless properly managed, soil fertility as well as quality decline drastically with intensive farm- 
ing. Maintenance of soil fertility is therefore very important for sustaining high yields of vegetation. In this line, a soil test can be an important management tool in developing an efficient soil fertility program and monitoring a field for potential soil and water management problems. A soil test provides basic information on the nutrient supplying capacity of the soil. The objective of this paper was to analyze the trend in fertility status of a paddy field of North Vanlaiphai, Mizoram with respect to seasonal variations.

Soil enzymes increase the reaction rate at which plant residues decompose and release plant available nutrients. The enzymatic reaction releases a product, which can be a nutrient contained in the substrate. Sources of soil enzymes include living and dead microbes, plant roots and residues, and soil animals. Enzymes stabilized in the soil matrix accumulate or form complexes with organic matter (humus), clay, and humus-clay complexes, but are no longer associated with viable cells. Enzymes respond to soil management changes long before other soil quality indicator changes are detectable. Soil enzymes play an important role inorganic matter decomposition and nutrient cycling. Some enzymes only facilitate the breakdown of organic matter (e.g., hydrolase, glucosidase), while others are involved in nutrient mineralization (e.g., amidase, urease, phosphatase, sulfates). The relationship may be indirect considering nutrient mineralization to plant available forms is accomplished with the contribution of enzyme activity.

\section{Methodology}

\section{Analysis of soil physico-chemical parameters}

Soil pH, bulk density, water holding capacity and soil moisture content was determined by using the method of Bashour and Sayegh ${ }^{5}$. Soil organic carbon, total soil nitrogen, available phosphorus was estimated by the method described by Walkley and Black ${ }^{6}$, Jackson et al. ${ }^{7}$ and Olsen et al. ${ }^{8}$ respectively. Soil enzymes, dehydrogenase, Phosphatase and urease were determined by using the method of Casida et al. ${ }^{9} \mathrm{Ta}-$ batabai et al. ${ }^{10}$ and Mc Garity et al. ${ }^{11}$, respectively.

\section{Statistical analysis}

All data are presented as means of three replicates with standard error. Differences between variables were tested with standard one-way analysis of variance (ANOVA), significant differences existed in all the parameters except parameter 3 that is Bulk density (Table 4). Differences were considered as significant at $P<0.05$ levels. The statistical analyses were performed using SPSS software (Standard release version 16 for windows, SPSS Inc., IL, USA).

\section{Results and Discussion}

Soil parameters were studied in different seasons of the year viz. rainy season, winter and summer. Results showed that all the soil parameters varied under the influence of seasonal variations (Table $1 \& 2$ ). The $\mathrm{pH}$ of the soil found to be lowest in rainy season (4.7), followed by winter and highest in summer (5.29). Decreased $\mathrm{pH}$ during rainy season may be due to decomposition of organic matter which releases organic acids leading to leaching of bases under prevailing high rainfall. ${ }^{12-13}$ Soil organic carbon; soil organic matter and total soil nitrogen were highest during rainy season. During this study period, amount of nitrogen in $\mathrm{kg} \mathrm{ha}^{-1}$ followed the order rainy season $(0.27)>$ winter $(0.17)>$ summer $(0.14)$. When soil is warm and moist, decomposition proceeds rapidly and nitrogen released from

Table 1 | Soil physical properties.

\begin{tabular}{lccc}
\hline Soil properties & Rainy season & Winter & Summer \\
\hline Temperature $\left({ }^{\circ} \mathrm{C}\right)$ & $25.27 \pm 0.08$ & $19.33 \pm 0.23$ & $25.97 \pm 0.22$ \\
\hline Moisture Content (\%) & $77.8 \pm 2.90$ & $46.65 \pm 1.81$ & $8.03 \pm 0.11$ \\
\hline Bulk Density $\left(\mathrm{gm} / \mathrm{cm}^{3}\right)$ & $0.91 \pm 0.02$ & $1.05 \pm 0.02$ & $1.03 \pm 0.03$ \\
\hline
\end{tabular}


Table 2 | Soil chemical properties.

\begin{tabular}{lccc}
\hline Soil properties & Rainy season & Winter & Summer \\
\hline Soil pH & $4.7 \pm 0.01$ & $4.87 \pm 0.07$ & $5.29 \pm 0.00$ \\
\hline Soil organic carbon (\%) & $2.86 \pm 0.04$ & $1.34 \pm 0.00$ & $1.02 \pm 0.03$ \\
\hline Soil organic matter (\%) & $4.93 \pm 0.08$ & $2.31 \pm 0.00$ & $1.76 \pm 0.06$ \\
\hline Total soil nitrogen (\%) & $0.27 \pm 0.00$ & $0.17 \pm 0.00$ & $0.14 \pm 0.00$ \\
\hline Available phosphorus (kg/ha) & $3.96 \pm 0.04$ & $4.23 \pm 0.02$ & $3.64 \pm 0.05$ \\
\hline Exchangeable potassium (kg/ha) & $136.38 \pm 3.05$ & $135.43 \pm 1.24$ & $151.3 \pm 1.11$
\end{tabular}

Table 3 | Soil enzyme activity.

\begin{tabular}{llll}
\hline Enzymes & Rainy season & Winter & Summer \\
\hline Dehydrogenase $(\mu \mathrm{g}$ TPF/gm dry soil/24hrs) & $0.81 \pm 0.06$ & $0.13 \pm 0.00$ & $0.09 \pm 0.00$ \\
\hline Phosphatase $(\mu \mathrm{g} \mathrm{p-NPP/gm} \mathrm{dry} \mathrm{soil/hr)}$ & $89.86 \pm 1.70$ & $49.36 \pm 1.34$ & $48.73 \pm 0.78$ \\
\hline Urease $\left(\mathrm{NH} 4^{+}-\mathrm{N} / \mathrm{ml} / 3 \mathrm{hrs}\right)$ & $1.10 \pm 0.01$ & $0.84 \pm 0.00$ & $0.56 \pm 0.00$ \\
\hline
\end{tabular}

Table 4 | One-way analysis of variance (ANOVA).

\begin{tabular}{clccc}
\hline SI. No. & Parameters & Source of variance & f-value & p-value \\
\hline 1 & Soil temperature & Rainy season X Winter X Summer & $178.4229^{*}$ & $.000005^{*}$ \\
\hline 2 & Soil moisture content & - do- & $156.0891^{*}$ & $.000007^{*}$ \\
\hline 3 & Bulk density & - do- & 3.5191 & .097453 \\
\hline 4 & Soil pH & - do- & $21.9284^{*}$ & $.001743^{*}$ \\
\hline 5 & Soil organic carbon & - do- & $382.6270^{*}$ & $.000000^{*}$ \\
\hline 6 & Soil organic matter & - do- & $388.1868^{*}$ & $.000000^{*}$ \\
\hline 7 & Total soil nitrogen & - do- & $259.4000^{*}$ & $.000001^{*}$ \\
\hline 8 & Available phosphorus & - do- & $27.4648^{*}$ & $.000955^{*}$ \\
\hline 9 & Exchangeable Potassium & - do- & $9.7898^{*}$ & $.012905^{*}$ \\
\hline 10 & Dehydrogenase & - do- & $125.4613^{*}$ & $.000013^{*}$ \\
\hline 11 & Phosphatase & - do- & $227.8959^{*}$ & $.000002^{*}$ \\
\hline 12 & Urease & - do- & $533.4444^{*}$ & $.000000^{*}$ \\
\hline
\end{tabular}

crop residues may be significant, but when soil is cold or very dry, nitrogen released may be lesser. ${ }^{14}$

Percentage of soil organic carbon and soil organic matter followed the order rainy season (2.86 and 4.93)> winter (1.34 and 2.31)>(1.02 and 1.76), respectively. Soil carbon content is positively correlated with soil organic matter. ${ }^{15}$ Low level of phosphorus and potassium may be attributed to removal of crop residues and grazing of livestock, ${ }^{16}$ leaching from poor sandy soil, ${ }^{17}$ and due to high rainfall. ${ }^{18}$

Soil enzymes showed the same trend in our data (Table 3 ), highest in rainy season and low- est during summer. Soil enzymes have varying optimum $\mathrm{pH}$ and temperature at which they function most efficiently. Their structure and substrate binding ability can be altered by heat and extreme cold temperature. The activity of many soil enzymes often correlates with soil moisture content, drought may suppress enzyme activity. Chhonkar et al. ${ }^{19}$ described positive correlation of phosphates activity with soil organic carbon and negative correlation with soil $\mathrm{pH}$. Soil enzymes activity can be related to soil organic matter and total soil nitrogen. ${ }^{20-21}$ All these features could be attributed to the increased amount of enzyme activity during rainy 
season and decreased rate during summer.

\section{Conclusion}

The comparative study of biochemical and physico-chemical properties of $\mathrm{N}$. Vanlaiphai paddy field soil during the three seasons' viz. rainy, winter and summer, showed significance $(\mathrm{p}<0.05)$ variation among all the parameters except bulk density. It $t$ is assumed that different seasonal pattern has effect on biochemical and physico-chemical properties of the soil.

\section{Acknowledgement}

The authors are thankful to Council of Scientific and Industrial Research (CSIR), New Delhi, Government of India for financial assistance.

\section{References}

I. Sahrawat, K.L. \& Wani, S.P. (2013). Soil testing as a tool for on-farm fertility management: experience from the semi-arid zone of India. Communications in Soil Science and Plant Analysis 44, IOII-IO32.

2. Tomer, M.D. \& Liebman, M. (2014). Nutrients in soil water under three rotational cropping systems Iowa, USA. Agriculture Ecosystem and Environment 186, I05II4.

3. Milder, J.C., Garbach, K., DeClerck, F.A.J., Driscoll, L. \& Montenegro, M. (20I2). An assessment of the multifunctionality of agroecological intensification. A report prepared for the Bill \& Melinda Gates Foundation.

4. Penüelas, J., Poulter, B., Sardans, J., Ciais, P., van der Velde, M., Bopp, L., Boucher, O., Godderis, Y., Hinsinger, P., Llusia, J., Nardin, E., Vicca, S., Obersteiner, M. \& Janssens, IA. (2013). Human-induced nitrogen-phosphorus imbalances alter natural and managed ecosystems across the globe. Nature Communication 4, I-IO.

5. Bashour, II. \& Sayegh, A.H. (2007). Methods of analysis for soils of arid and semi-arid regions. Food and Agriculture Organization of the United Nations. Rome I5-37.

6. Walkley, A. \& Black, I.A. (1934). An examination of the Degtjareff method for determining organic carbon in soil: In effect of variation in digestion condition and of inorganic soil constituent. Soil Science 63, 251-263.
7. Jackson, M.L. (1973). Soil Chemical Analysis. New Delhi, Prentice Hall India (P) Limited.

8. Olsen, S.R., Cole, C.V., Watanabe, F.S. \& Dean, L.A. (1954). Estimation of available phosphorus in soils by extraction with sodium bicarbonate. US Department of Agriculture Circular No. 939.

9. Casida, L.E. (1977). Microbial metabolic activity in soil as measured by dehydrogenase determinations. Applied Environmental Microbiology 34, 630-636.

Io. Tabatabai, M.A. \& Bremner, J.M. (1969). Use of pnitrophenylphosphate for assay of soil phosphatase activity. Soil Biology and Biochemistry 1, 30I-307.

II. Mc Garity, J.W. \& Myers, M.G. (1967). A survey of urease activity in soil of northern New South Wales. Plant and soil 27, 217-238.

I2. Conyers, M.K, Uren, N.C. \& Helyar, K.R. (1995). Causes of changes in $\mathrm{pH}$ in acidic mineral soils. Soil Biology and Biochemistry 27, 1383-1392.

13. Yan, F., Schubert, S. \& Mengel, K. (1996). Soil pH changes during legume growth and application of plant material. Biology and Fertility of Soils 23, 236-242.

I4. Eckert, D. (20I0) Efficient Fertilizer Use-Nitrogen. I-I9

I5. Soon, Y.K. \& Arshad, M.A. (1996). Effects of cropping systems on nitrogen, phosphorus and potassium forms and soil organic carbon in gray luvisol. Biology and Fertility of Soils 22, I84-190.

I6. Bolland, M.D.A. (1987). Phosphorus deficiency in narrow-leafed lupins. Farmnote no. 62/87, Agdex 161/632. Dept Agric. WA, Perth

17. Bolland, M.D.A., Yeates, J.S. \& Clarke, M.F. (1996). Effect of fertilizer type, sampling depth, and years on Colwell soil test phosphorus for phosphorus leaching soils. Fertilizer Research 44, 177-188.

I8. Bolland, M.D.A., Cox, W.J. \& Codling, B.J. (2002). Soil and tissue tests to predict pasture yield responses to applications of potassium fertilizer in high rainfall areas of south-western Australia. Australian Journal of Experimental Agriculture 42, I49-164.

19. Chhonkar, P.K. \& Tarafdar, J.C. (1984). Accumulation of phosphatases in soils. Journal of Indian Society of Soil Science 32, 266-272.

2o. Aon, M.A. \& Colaneri, A.C. (200I). Temporal and spatial evolution of enzymatic activities and physicochemical properties in an agricultural soil. Applied Soil Ecology 18, 255-270.

2I. Noorbakhsh, F., Hajrasuliha, S. \& Emtiazy, G. (20oI). Factors affecting urease enzyme activity in some soils in Isfahan Province. JWSS-Isfahan University of Technology 5, 95-106. 